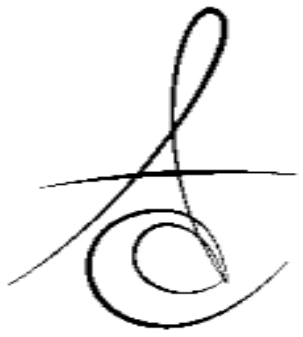

Makale Kodu/Article code: 1457 Makale Gönderilme tarihi: 10.01 .2014 Kabul Tarihi: 26.02.2014

\title{
FIBER FRAMEWORK REINFORCED COMPOSITE RESIN BRIDGE APPLICATIONS AS AN ALTERNATIVE PROCEDURE TO CLASSIC PROSTHODONTIC TREATMENTS: FOUR CASE REPORTS
}

\section{KLASİK PROTETİK TEDAVİLERE ALTERNATİF OLARAK FİBER ALTYAPI İLE GÜÇLENDİRİLMİ̧ KOMPOZITT REZİN KÖPRÜ UYGULAMALARI: DÖRT OLGU SUNUMU}

\section{ABSTRACT}

In some situations like, economic failure, general health problems or patient's fear to other more invasive operations, fiber-reinforced composite (FRC) resin bridge applications may be an alternative treatment method in single tooth missed cases.

A variety of treatment modalities, from implants to conventional Maryland bridges, can be used for replacing missed single tooth. In this article the purpose was to report FRC bridge restorations of missed single tooth in four cases (who did not want expensive treatment options or have health problems) and to evaluate the short-term clinical performance of such applications.

In four different patients with maxillar bilateral canine teeth absence, maxillar left second premolar tooth absence, maxillar left central incisor tooth absence and mandibular left central incisor absence the FRC adhesive bridges were designed and performed. The restorations have provided important benefits in addressing deficiencies mainly aesthetically, phonational and functional. These procedures were very effective in terms of patient satisfaction because of the fact that they were minimal invasive, conservative and economic. There were no clinical problem and patient dissatisfaction in any case after one year of follow-up.

FRC bridge applications can be a much more conservative alternative treatment option compared to conventional prosthetic restorations. Satisfactory results were obtained in the presented cases, but there is a need of longer follow-up clinical application results.

Key words: Fiber framework, fixed partial denture, composite bridge.

\author{
Dr. Serdar BAĞLAR
}

\section{ÖZET}

Ekonomik yetersizlik, sağlık problemleri veya hastanın daha girişimsel olan diğer uygulamalara olan korkusu gibi durumlarda fiber ile güçlendirilmiş kompozit (FGK) rezin köprü uygulamaları tek diş eksikliği vakalarında alternatif bir tedavi yöntemi olabilmektedir.

Tek diş eksikliklerinde geleneksel Maryland köprülerden implant uygulamalarına kadar çeşitli tedavi yöntemleri kullanılabilir. Bu makale de tek diş eksikliği bulunan dört vakanın sunumu (ki bu hastalar pahalı tedavileri istemeyen veya genel sağlık problemleri bulunan kişilerdir) ve kısa dönemli klinik performanslarının değerlendirilmesi amaçlanmıştır.

Maksiller iki taraflı kanin diş eksikliği, maksiller sol ikinci premolar diş eksikliği, maksiller sol santral diş eksikliği ve madibular sol santral diş eksikliği bulunan dört hastada adeziv FGK köprüler dizayn edildi ve uygulandı. Restorasyonlar estetik, fonksiyonel ve fonasyonel eksiklikleri giderme bakımından önemli faydalar sağladı. Bu tür uygulamalar az girişimsel, doku bütünlüğünü koruyucu ve ekonomik olmaları nedeniyle hasta memnuniyetini sağlama bakımından etkili olabilmektedirler. Sunulan vakaların bir yıllık takipleri sonucu herhangi bir hasta memnuniyetsizliği ve klinik probleme rastlanılmamıştır.

Geleneksel yöntemler ile kıyaslandığında FGK köprü uygulamaları çok daha doku koruyucudur. Sunulan vakalarda tatmin edici sonuçlar elde edilmiştir ancak daha uzun dönemli klinik takip sonuçları gereklidir.

Anahtar Kelimeler: Fiber altyapı, sabit bölümlü protez, kompozit köprü.

* Kırıkkale Üniversitesi Diş Hekimliği Fakültesi, Restoratif Diş Tedavisi Ana Bilim Dalı 


\section{INTRODUCTION}

The need to respond to the ever-increasing patient demand for aesthetics, tissue maintenance, and cost efficiency has resulted in the evolution of techniques and materials that allow predictable restorations of teeth that would otherwise be compromised. Adhesive restorations permit clinicians to create minimally invasive preparations, thereby preserving sound tooth structure. The development of synthetic dental materials has allowed the incorporation of fiber-reinforced materials to be used in conservative aesthetics treatments. These contemporary materials provide increased flexural strength, as well as improved aesthetics to the restoration. ${ }^{1}$. Different fiber types such as glass fibers, carbon fibers, kevlar fibers, vectran fibers, polyethylene fibers have been added to resin composite materials. $^{2}$

Glass fibers consisting of glass interlaced filaments, improve the impact strength of resin composite materials. They have excellent esthetic properties, but do not easily stick to resinous matrix. Carbon fibers prevent fatigue fracture and strengthen resin composite materials, but their color is dark, which is undesirable in esthetic dentistry. Kevlar fibers, made of aromatic polyamide, are the evolution of nylon polyamide. They increase the impact strength of resin composite materials. However, they are also unaesthetic, and hence, their use is very limited. Vectran fibers are a new generation of synthetic fibers made of aromatic polyesters. They show a good resistance to abrasion and impact strength, but they are expensive and not easily wielded. Polyethylene fibers improve the impact strength, modulus of elasticity and flexural strength of resin composite materials. Unlike carbon and Kevlar fibers, polyethylene fibers are almost invisible in a resinous matrix and for this reason, seem to be the most appropriate and esthetic strengtheners of resin composite materials. ${ }^{2-6}$ The use of ultra-high molecular weight polyethylene (UHMWP) fibers like "Ribbond" is based on the improvement of the resin composite mechanical properties and behaviors. ${ }^{7}$

Ribbond (Ribbond Inc., Seattle, WA, USA) is a reinforced ribbon, made of ultrahigh molecular weight polyethylene fiber that has an ultrahigh modulus. It is treated with cold gas plasma to enhance its adhesion to synthetic restorative materials, including chemically cured or light-cured resin composites. The special fiber network of this material allows efficient transfer of forces. It is virtually pliable and thus, adapts easily to tooth morphology and dental arch contours. Its translucency makes it an esthetic material and it can be cured with light-cured resin composites. Ribbond fibers can also be cut using special nippers without fraying or losing their original dimensions. ${ }^{8}$ Ribbond is a spectrum of 215 fibers with a very high molecular weight. First introduced to the market in 1992, Ribbond consists of bondable, reinforced ultra-highstrength polyethylene fibers with a high elasticity coefficient (117 GPa) that makes it highly resistant to stretch and distortion and a highly resistant to traction (3 GPa) that allows them to adapt easily to tooth morphology and dental-arch contours. Ribbond fibers easily absorb water because of the "gas-plasma" treatment to which they are exposed. This treatment reduces the fibers' superficial tension, ensuring a good chemical bond to composite materials. Ribbond is also biocompatible, aesthetic, translucent, and practically colorless and disappears within the resin composite or acrylic resins without show-through. Furthermore, Ribbond fibers are also characterized by an impact strength five times higher than that of iron. ${ }^{2-6,9,10} \mathrm{~A}$ variety of therapeutic modalities, from implants to conventional Maryland bridges, may be used for the replacement of missed single tooth. The reinforcement of resin composites by fibers improves their fracture toughness and resistance. Fiber-reinforced composite (FRC) bridges can be a good alternative to conventional prosthetic techniques.

In this case report, the applications of Ribbond framework inside of the resin composite edge restorations were reported in four cases as an alternative procedure to prosthodontic treatments.

\section{CASE REPORTS}

Case 1: Fiber bridge application in the absence of bilateral canine teeth

A 55 year-old-man with bilateral canine teeth absence was admitted to Kirikkale University Faculty of Dentistry for treatment. Although his main complaint was his aesthetic appearance; he also had phonation and functional discomforts. The clinical and radiographic examinations revealed that both of the 
permanent maxillary canine teeth were impacted (Figure 1). Possible treatment options were explained in detail to the patient including orthodontic treatment combined with surgery. He asked for the least traumatic option due to his cardiac by-pass operation history. Therefore, we suggested an alternative adhesive resin bridge restoration reinforced with fiber Ribbond (Ribbond Inc., Seattle, WA, USA) (Figure 2). After the patient's confirmation the treatment started.

In order to be as conservative as possible, $2 \mathrm{~mm}$ width minimal cavities were prepared at the palatinal sides of the second incisors and first premolar teeth. Cavity preparations were limited to enamel and dentin was not damaged. Interdental spaces including the cavity lengths were measured and $2 \mathrm{~mm}$ width Ribbond bands were cut. The Ribbond bands were stored in bonding resin (Clearfil SE Bond, Kuraray, Osaka, Japan) while the cavities were prepared. A thin $0,5 \mathrm{~mm}$ layer of flowable resin composite (3M Filtek Flow, 3M ESPE, St.Paul, USA) was placed at the cavity bases. Then bonding-soaked fiber Ribbonds were adapted on this layer being convex towards the labial side and light cured for 20 seconds (Hilux 350; First Medica, Greensboro, NC) (Figure 3) and the resin composite pontic bodies were builded on the Ribbond framework by incremental layering technique using Filtek-Ultimate (3M ESPE) resin composite (Figure 4). Occlusal contacts were checked and adjustments were made if necessary. At the first month recall evaluation, there were no problems or fractures on the restoration and there was no patient discomfort.

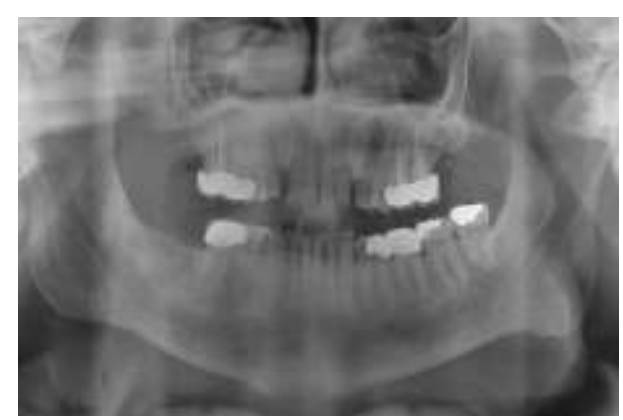

Figure 1. Impacted permanent canine teeth were shown in the panoramic radiograph

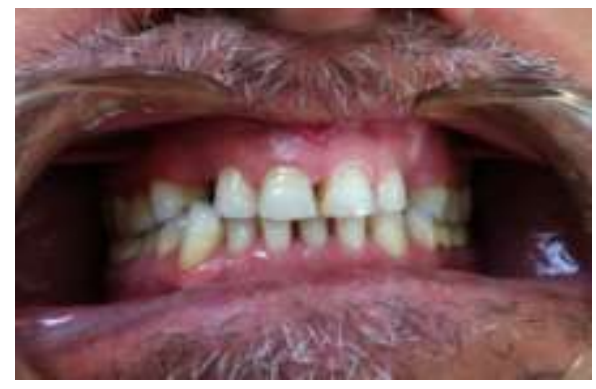

Figure 2. Intraoral view of bilateral upper canine teeth absence.

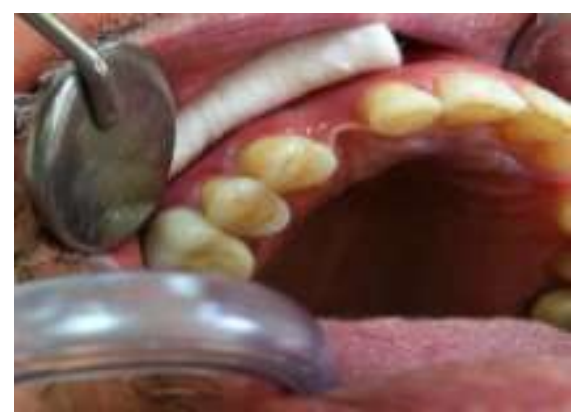

Figure 3. The view of the Ribbond band placed in the prepared cavities.

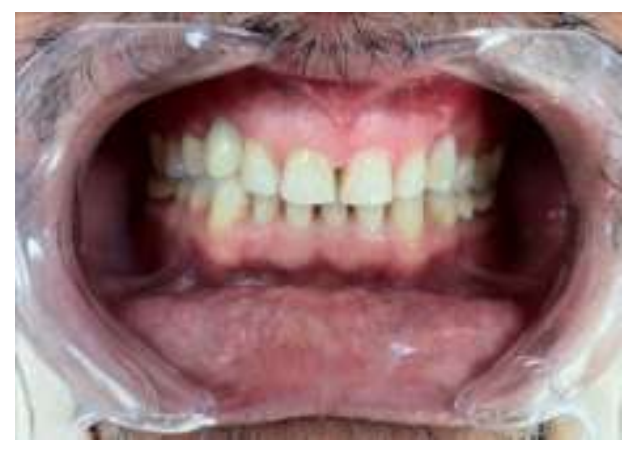

Figure 4. View of the finished FRC restorations.

\section{Case 2: Fiber bridge application in the absence of second upper premolar tooth}

A 26 year-old-woman with maxillary left second premolar tooth absence was applied to our clinic with the complaints of aesthetic appearance and functional disability. The patient was informed that the single tooth absence had two conventional treatment options like implant or classic bridge applications. The patient explained that she did not have any economical

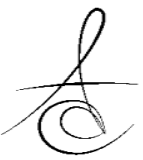


resources for implant restorations and that she didn't want much tissue loss on her sound teeth for a bridge treatment. In the clinical and radiographic examinations, caries were noticed at the distal part of first premolar and at the mesial part of the first molar teeth. Consequently, a cavity preparation for a restoration was inevitable and this necessity allowed us to create a more conservative and economic option like a fiber reinforced resin composite inlay bridge restoration. After the patient's consent the treatment started. Following caries removal the class II cavities were prepared (Figure 5-6). Since the patient had a temporomandibular joint dysfunction, the treatment was deeded to be done indirectly. Impressions were taken using an irreversible hydrocolloid impression material (Alginoplast, Heraeus Kulzer Gmbh, Germany) to obtain plaster models (Figure 7). The space between the teeth including the cavity lengths was measured. Two Ribbond bands were cut in appropriate lengths and the models were isolated. A 1 $\mathrm{mm}$ resin composite increment (Filtek Supreme Ultimate 3M ESPE) was positioned in each axial wall to retain the previously adhesive moistened (Clearfil SE Bond, Kuraray, Osaka, Japan) fiber. The fiber was positioned with its ends within the cavities on the nonpolymerized resin composite, following pulpal and axial preparation contours. In the pontic region, the fiber was positioned $2 \mathrm{~mm}$ above the gingival area. Then, the resin composite and the fiber were polymerized for 40 seconds (Hilux 350; First Medica, Greensboro, NC). An additional $1 \mathrm{~mm}$ increment was placed and another polyethylene fiber was positioned in the same way as the previous one. Then the missed second premolar tooth and cavities were manually built-up on the Ribbond framework by using resin composite material (Filtek Supreme Ultimate 3M ESPE) (Figure 7). This resin composite bridge was controlled in mouth for early contacts and incompatibilities. After polishing, the resin composite bridge was fixed by using a dual-cure resin cement according to manufacturer's instructions (Panavia F, Kuraray, Osaka, Japan) (Figure 8). After the first month and one year recalls, there were no fractures or other problems and the patient had no complaints.

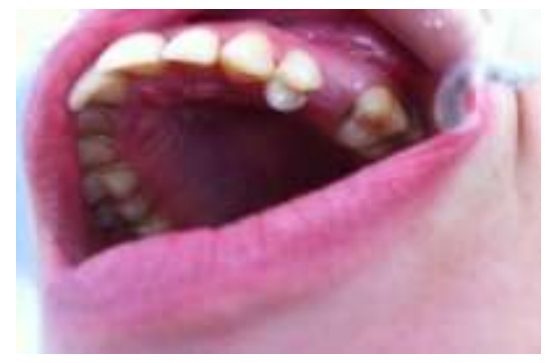

Figure 5. Intraoral view of upper premolar tooth absence in second case.

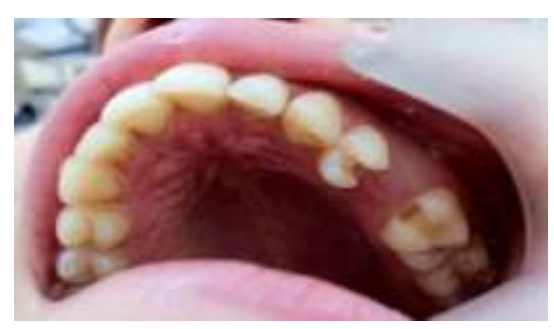

Figure 6. View of the caries removed class II cavities.

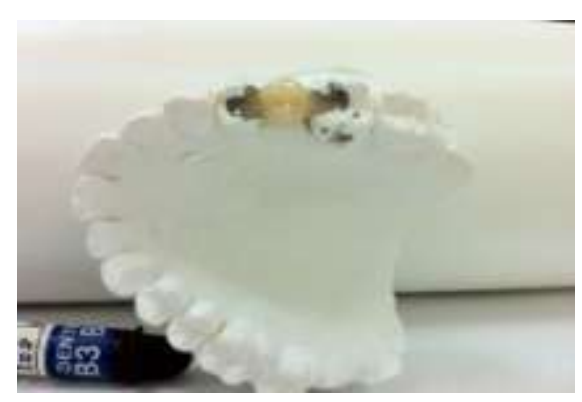

Figure 7. View of the extraoral builded FRC bridge.

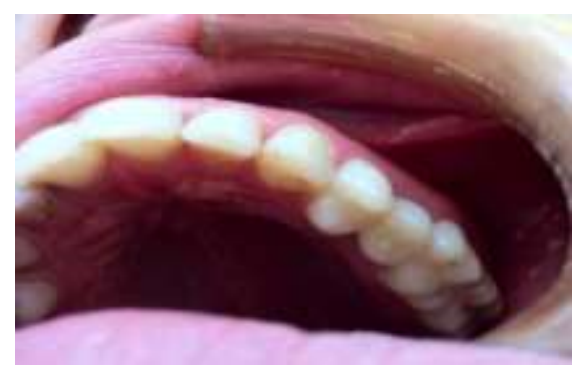

Figure 8. View of the finished and bonded FRC bridge.

Case 3: Fiber bridge application in the absence of upper left incisor tooth

A 63 year-old-woman with a maxillary left central incisor tooth absence applied to our clinic (Figure 9). The patient's prominent complaints were

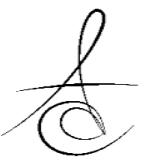


her aesthetic appearance, phonation and functional disabilities. Treatment options (implant, partial denture) for the situation of the patient's absent tooth were explained. The patient declared that considering her economic condition, the implant option was not suitable for her. She mentioned that she did not prefer her teeth to be prepared for a bridge appliance. Considering her preferences and the actual situation, a fiber reinforced bridge was advised. In the clinical and radiographic examinations, caries were noticed at the mesial of the right central incisor and at the mesial of the left lateral teeth, therefore they were already in need of caries treatment. Treatment started after the patient's confirmation. Firstly, conservative cavities were prepared which were $2 \mathrm{~mm}$ width minimal cavities at the palatinal gingival one-third of the lateral and central incisor teeth. Interdental spaces including the cavities lengths were measured and a $2 \mathrm{~mm}$ width Ribbond bands were cut. Then bonding-soaked fiber ribbon was adapted to the cavities. Ribbond was shaped to be convex towards the labial and light cured 20 seconds. An additional Ribbond was positioned vertically in order to provide a basis for the pontic modelation. The modelation of the pontic was completed with an appropriate shade of resin composite by an incremental layering technique. A gingiva-colored resin composite (Anaxgum gingival paste,

ANAXDENT, Stuttgart, Germany) was used to compensate the alveolar bone resorption and to provide an aesthetic appearance. Occlusal contacts were checked and abrasions were made where necessary. At first month and first year recalls, we evaluated the restoration for any problems or fractures and there were no fractures or any other problems. The patient was satisfied (Figure 10).

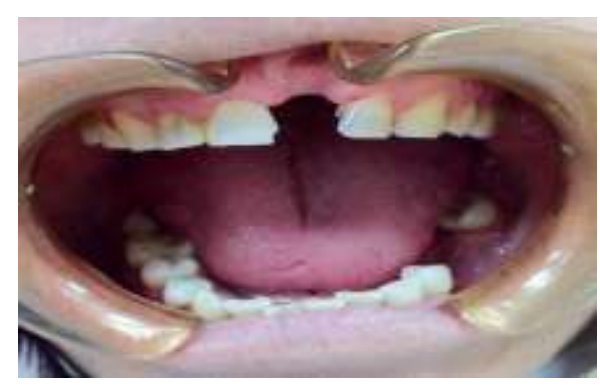

Figure 9. Intraoral view of upper left central tooth absence in third case.

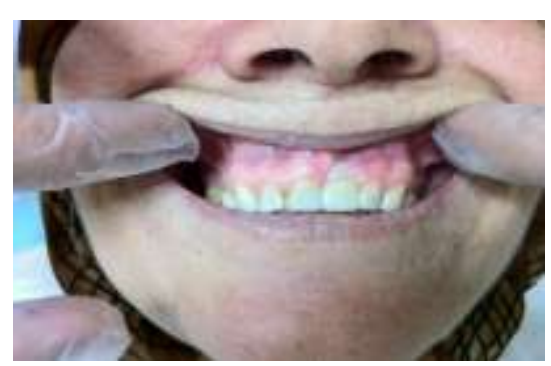

Figure 10. View of the finished FRC bridge.

\section{Case 4: Fiber bridge application in the absence of the lower left central incisor tooth}

A 20 year-old man with a missing mandibular central incisor was evaluated for restorative treatments. His chief complaints were his poor aesthetics and lack of biting functions (Figure 11). Clinical and radiographic examinations were completed. Intraoral examination revealed a healthy dentition and healthy periodontal tissues. Restorative options were discussed (fixed denture, implant) and explained to the patient. He didn't accept fixed denture or implant options. The alternative treatment choice with fiber reinforced bridges was accepted by the patient after being informed in detail.

$2 \mathrm{~mm}$ width minimal cavities were prepared at the lingual surfaces of the adjacent teeth. Interdental spaces and cavities' lengths were measured and Ribbond bands were stored in bonding resin (Clearfil SE Bond). A thin layer of flowable composite resin (3M Filtek Flow, 3M ESPE) was placed at the cavity bases. Then bonding soaked fiber Ribbond was adapted to the cavities on the flowable resin composite and light cured 20 second (Figure 12), then resin composite (Filtek Supreme Ultimate) build-up was performed. Occlusal contacts were evaluated. Polishing procedure was completed (Figure 13). At one month and one year, we checked the restoration and there were no problems or fractures.

In all cases; at the gingival regions of the pontics, preshaped transparent tapes were used while modeling these areas before polimerization to prevent soft tissues from excessive contacts. Pontic bodies were designed in hygienic form to allow easy cleaning.

Also in all cases the polishing procedures were made using finishing burs and polishing discs (Sof-Lex Contouring \& polishing discs, 3M ESPE, St. Paul, USA)

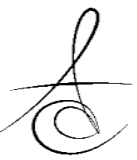


as in conventional resin composite restorations. Polishing discs were applied under water and air cooling at 10 thousand rpm with micro-motor for one minute average for each tooth.

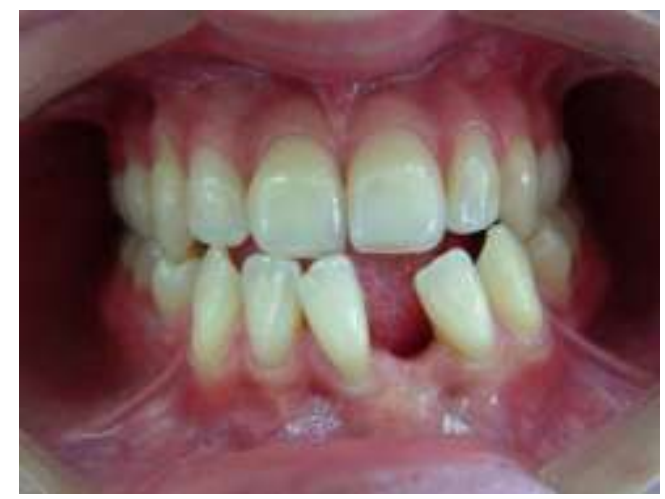

Figure 11. Intraoral view of lower left central tooth absence in fourth case.

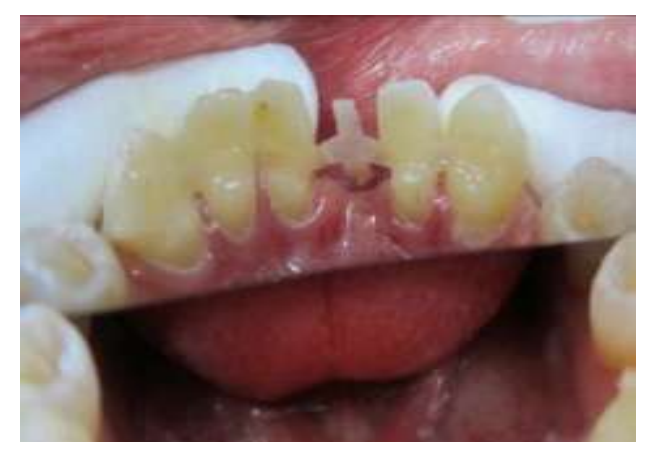

Figure 12. Intraoral view of the builded Ribbond framework.

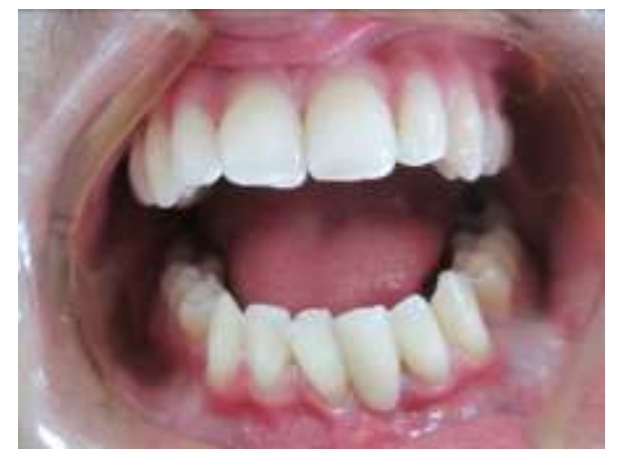

Figure 13. View of the finished FRC bridge.

\section{DISCUSSION}

Since 1991, polyethylene fibers have been successfully used in a variety of clinical techniques. ${ }^{11,12}$ This study was a short-term clinical-follow up, evaluating the performance of adhesively bonded fiberreinforced resin composite bridges at the different regions of the dental arch. In recent years, new developments in resin technology and patient demand for tooth-colored restorations led to an increased use of resin-bonded fiber-reinforced bridges to replace single missing tooth, as reported in previous studies. ${ }^{13-20}$

In a study, it was reported that the metal framework fixed bridges showed $61 \%$ overall and $76 \%$ functional survival rates while fiber-reinforced bridges had significantly higher overall and functional survival (75\% and $93 \%$ respectively). ${ }^{21}$ Although it is not possible to directly compare metal-ceramic to fiber-reinforced FPDs with regard to their mechanical properties, when considering their survival, they should be compared considering their cost, timeconsuming procedure, material color, presence of adhesive and tissue-saving properties. ${ }^{22}$

In various studies clinicians have evaluated the fiber-reinforced adhesively-bonded resin composite prostheses in terms of function, aesthetic and overall clinical successes and about survival rates. And it have reported that this kind of restorations functioned adequately during their clinical follow-up period times ranging from 1 to 8 years and with survival rates ranging from $75 \%$ to $95 \% .23-27$

Cases evaluated in this report were similar to these studies and showed acceptable clinical performance after 1 year which may be promising in terms of long-term successes.

Longevity of "fiber-reinforced resin composite" bridge restorations dependent upon many different factors, including material, maxillary or mandibular arches, patient- and dentist. Moreover, patient factors such as oral hygiene, dietary habits, preventive measures, fluoride availability, compliance in recall and cooperation during treatment, and oral environment are relevant topics when considering the restoration durability. ${ }^{24}$ Although the evidence that inlay FPDs placed in the mandible show a higher failure risk than those placed in the maxilla. ${ }^{28}$ In the present article, reported cases were mixed restorations placed both in maxilla and mandibula and 
showed similar clinical results in short-term evaluation.

In their three-dimensional (3D) finite element (FE) analysis study, Yokoyama et al. ${ }^{29}$ investigated the optimal design of a fiber-reinforced composite (FRC) framework to obtain the maximum reinforcement for fixed partial dentures (FPDs) under three different loading conditions. A 3D FPD replacing the maxillary right lateral incisor was constructed using $\mathrm{FE}$ analysis software (ANSYS 10.0, ANSYS) in the study. A fiber framework of the pontic was designed with three variations: with the main framework curved labially (FRC1), located in the center (FRC2), or curved lingually (FRC3). They reported that, localized high stress concentration was observed around the connectors under all loading conditions. In all FRC-FPD models, the FRC framework showed stress-bearing capacity for the FPD. The highest stress reduction ratio under all loading conditions was obtained using the FRC1 model. According to these results, the authors suggested that the optimum design of an FRC framework is a labially curved design at the region of the pontic. Therefore, in our anterior bridge restorations (cases 1,3 and 4) the FRC frameworks were designed as being labially curved.

Chen et al. $^{30}$ evaluated the validation of a shape-optimized fiber-reinforced dental bridge in their in-vitro study. To improve its mechanical performance, structural optimization had been used in their study to obtain an alternative design for a 3-unit inlay-retained fiber-reinforced composite (FRC) dental bridge. An optimized layout of the FRC substructure had been proposed to minimize stresses in the veneering composite and interfacial stresses between the composite and substructure when compared with conventional design. The authors reported that, the load-displacement curves of the two groups displayed significant differences. For the conventional design, there were numerous drops in load corresponding to local damage of the sample. For the optimized design, the load curves were much smoother. Cracks were clearly visible on the surface of the conventional group only, and the directions of those cracks were perpendicular to those of the most tensile stresses. They suggested that the optimized design, similar to our framework design, will significantly improve the clinical performance of FRC bridges.

\section{CONCLUSION}

Further clinical investigations are needed for improved long-term clinical performance, as clinical trials with larger number of inlay FPDs could confirm or decline the clinical performance success of fiberreinforced adhesive partial dentures.

\section{REFERENCES}

1. Rappelli G, Putignano A. Tooth splinting with fiber-reinforced composite materials: Achieving predictable aesthetics. Pract Proced Aesthet Dent 2002;14:495-500.

2. Vitale MC, Caprioglio C, Martignone A, Marchesi U, Botticelli AR. Combined technique with polyethlene fibers and composite resins in restoration of traumatized anterior teeth. Dent Traumatol 2004;20:172-7.

3. Vallittu PK, Vojtkova H, Lassila VP. Impact strength of denture polymethyl methacrylate reinforced with continuous glass fibers or metal wire. Acta Odontol Scand 1995;53:392-6.

4. Uzun G, Hersek N, Tincer T. Effect of five woven fiber reinforcements on the impact and transverse strenght of a denture base resin. J Prosthet Dent 1999;81:616-20.

5. DeBoer J, Vermilyea SG, Brady RE. The effect of carbon fiber orientation on the fatigue resistance and bending properties of two denture resins. J Prosthet Dent 1984;51:119-21.

6. Berrong JM, Weed RM, Young JM. Fracture resistance of Kevlar-reinforced poly(methyl methacrylate) resin: a preliminary study. Int J Prosthodont 1990;3:391-5.

7. Colán Guzmán P, Freitas FF, Ferreira PM, Freitas $C A$, Reis KR. Influence of different cantilever extensions and glass or polyaramide reinforcement fibers on fracture strength of implant-supported temporary. J Appl Oral Sci 2008;16:111-5.

8. Vallittu PK. Ultra-high-modulus polyethylene ribbon as reinforcement for denture polymethyl methacrylate: A short communication. Dent Mater 1997;13:381-2.

9. Ganesh M, Tandon S. Versatility of ribbond in contemporary practice. Trends Biomater Artif Organs 2006; 20:53-8. 
10. Karaman AI, Kir N, Belli S. Four applications of reinforced polyethylene fiber material in orthodontic practice. Am J Orthod Dentofacial Orthop 2002;121:650-4.

11. Heling I, Gorfil C, Slutzky H, Kopolovic K, Zalkind M, Slutzky-Goldberg I. Endodontic failure caused by inadequate restoration procedures: review and treatment recommendations. J Prosthet Dent 2002;87:674-8.

12. Rudo DN, Karbhari VM. Physical behaviors of fiber reinforcement as applied to tooth stabilization. Dent Clin North Am 1999;43:7-35.

13. Ajlouni R, Ajlouni K, Oonsombat C, Ruder G. Conservative inlay fixed partial denture: a clinical and laboratory technique. Gen Dent 2005;53:2669.

14. Belvedere PC. Single-sitting, fiber-reinforced fixed bridges for the missing lateral or central incisors in adolescent patients. Dent Clin North Am 1998;42:665-82.

15. Ferreira ZA, Carvalho EK, Mitsudo RS, Bergamo PM. Bondable reinforcement ribbon: clinical applications. Quintessence Int 2000; 31:547-52.

16. Rappelli G, Coccia E. Fiber-reinforced composite fixed partial denture to restore missing posterior teeth: a case report. J Contemp Dent Pract. 2005;6:168-77.

17. Trushkowsky R. Fiber-reinforced composite bridge and splint. Replacing congenitally missing teeth. N Y State Dent J 2004;70:34-8.

18. Karaalioğlu O, Duymuş ZY. Fiberle Güçlendirilmiş Kompozitlerin Sabit Bölümlü Protez Yapımında Kullanımları. Fiber Reinforced Composites Used In Fixed Partial Dentures. Atatürk Üniv Diş Hek Fak Derg 2008;18:70-7.

19. Karaalioğlu O, Aladağ Lİ. Cam Fiber İle Güçlendirilmiş Kompozit Rezin Köprü Restorasyonu-Vaka Raporu. Glass Fiber Reınforced Composite Resın Fixed Partıal Dentures-Case Report. Atatürk Üniv Diş Hek Fak Derg 2009; 19:111-4.

20. Güngör H, Kürklü D, Holoğlu B. Fiber İle Güçlendirilmiş Rezin Tutuculu Köprü Restorasyonu: Olgu Sunumu. Fıber Reınforced Resın-Bonded Brıdge: Case Report. Atatürk Üniv Diş Hek Fak Derg 2010; Suplement 3:21-4.
21. Pröbster B, Henrich GM. 11-year follow-up study of resinbonded fixed partial dentures. Int J Prosthodont 1997; 10:259-68.

22. van Heumen CCM, Kreulen CM, Creugers NHJ. Clinical studies of fiber-reinforced resin-bonded fixed partial dentures: a systematic review. Eur ] Oral Sci 2009;117:1-6.

23. Cenci M.S, Rodolpho P.A.R., Cenci T.P, Cury A.A., Demarco F.F. Fixed partial dentures in an up to 8year follow-up. J Appl Oral Sci 2010;18:364-71.

24. Piovesan EM, Demarco FF, Piva E. Fiber-reinforced fixed partial dentures: a preliminary retrospective clinical study. J Appl Oral Sci 2006;14:100-4.

25. Unlu N, Belli S. Three-year clinical evaluation of fiber-reinforced composite fixed partial dentures using prefabricated pontics. J Adhes Dent 2006;8:183-8.

26. Freilich MA, Meiers JC, Duncan JP, Eckrote KA, Goldberg AJ. Clinical evaluation of fiber-reinforced fixed bridges. J Am Dent Assoc 2002;133:1524-34.

27. Benjamin G, Kurtzman GM. An indirect matrix technique for fabrication of fiber-reinforced direct bonded anterior bridges. Compend Contin Educ Dent 2010;31:60-4.

28. Creugers $\mathrm{NH}$, Van't Hof MA. An analysis of clinical studies on resin-bonded bridges. J Dent Res 1991;70:146-9.

29. Yokoyama D, Shinya A, Lassila LV, Gomi H, Nakasone Y, Vallittu PK, Shinya A. Framework design of an anterior fiber-reinforced hybrid composite fixed partial denture: a 3D finite element study. Int J Prosthodont 2009;22:405-12.

30. Chen $Y$, Li $H$, Fok $A$. In vitro validation of a shapeoptimized fiber-reinforced dental bridge.Dent Mater 2011;27:1229-37.

\author{
Yazışma Adresi \\ Dr. Serdar BAĞLAR \\ Kırıkkale Üniversitesi Diş Hekimliği Fakültesi \\ Restoratif Diş Tedavisi Anabilim Dalı \\ KIRIKKALE \\ TIf: 03124753488 \\ E-posta: serdarbaglar78@gmail.com
}

